\title{
PERBEDAAN KETIDAKWAJARAN SKOR BERDASARKAN TEORI RESPON BUTIR DITINJAU DARI MODEL PENSKORAN JAWABAN SISWA SMP SE KOTA PALANGKA RAYA
}

\author{
(Difference of Unfair Score Based on the Item Response Theory (IRT) Reffered to the Model \\ of Students' Answers Scoring of Junior High School Sthroughout the City of Palangka Raya)
}

\section{SUGIHARTO}

Program Studi Pendidikan Matematika Fakultas Keguruan dan dan IImu Pendidikan Universitas Palangka Raya Kampus UPR : Jl. Yos Sudarso Palangka Raya, Kalimantan Tengah 73111

e-mail : giharto64@yahoo.com

\begin{abstract}
This study aims to know about the difference of unfair score based on item response theory reffered to the model of students' answers scoring of Junior High Schools throughout the city of Palangka Raya. The samples were taken from 17 state and private Junior High Schools throughout the city of Palangka Raya. The instrument was in the form of a multiple choice test with three options that included math materials of Junior High School in the seventh grade students in second semester of 2015/2016. Furthermore, the students' answers were corrected by using scoring models, namely punishment score and correct score. Before doing the test to take the data, the data had to be validated first, both in the content and empirical data. From the 40 test items, they were obtained 30 valid items. To obtain the proportion of fair score, it was used the estimation using BILOG-MG program. Furthermore, the data were analyzed with the different proportions $(Z)$ of two groups.

The results of the data analysis showed that $Z_{\text {count }}$ is -2.806 , while $Z_{\text {table }}$ is -1.65 so $Z_{\text {count }}$ rank outside the receipt area of $\mathrm{H}_{0}$. It shows that the students with the scoring models of punishment score encompass the score that more than the scoring models of correct score with a significant difference in the proportion. It can be concluded that the students who were corrected by using scoring models of punishment score have a fair index better than the fair index of the students were corrected by using scoring models of correct score.
\end{abstract}

Keywords: the unfair score, scoring models

\section{ABSTRAK}

Penelitian ini bertujuan untuk mengetahui perbedaan ketidakwajaran skor berdasarkan teori respon butir ditinjau dari model penskoran siswa SMP se Kota Palangka Raya. Sampel diambil dari 17 SMP negeri dan swasta yang ada di Kota Palangka Raya. Instrumen berupa tes pilihan ganda dengan tiga pilihan yang mencakup materi matematika SMP Kelas VII semester genap tahun 2015/2016. Selanjutnya dikoreksi dengan model penskoran punishment score dan correct score. Sebelum tes digunakan untuk mengambil data terlebih dahulu dilakukan validasi, baik isi maupun empiris. Dari 40 butir soal tes diperoleh 30 butir soal yang valid. Untuk memperoleh data proporsi skor wajar digunakan estimasi menggunakan program BILOG-MG. Selanjutnya data dianalisis dengan perbedaan proporsi (Z) dua kelompok.

Hasil analisis data menunjukkan bahwa $Z_{\text {hitung }}$ sebesar $-2,806$, sedangkan $Z_{\text {tabel }}$ adalah $-1,65$ sehingga $Z_{\text {hitung }}$ terletak di luar daerah penerimaan $\mathrm{H}_{0}$. Hal ini menunjukkan bahwa pada siswa dengan model penskoran punishment score menjaring skor lebih banyak dibandingkan dengan model penskoran correct score dengan perbedaan proporsi yang signifikan. Dapat disimpulkan bahwa siswa yang dikoreksi dengan model penskoran punishment score mempunyai indeks kewajaran yang lebih baik dibandingkan dengan indeks kewajaran siswa yang dikoreksi dengan model penskoran correct score.

Kata kunci : ketidakwajaran skor, model penskoran

\section{PENDAHULUAN}

Evaluasi merupakan salah satu lingkup yang memerlukan standarisasi dalam meningkatkan mutu pendidikan. Sebagai instrumen utama dalam evaluasi adalah tes. Tes merupakan suatu upaya untuk melakukan pengukuran terhadap tingkat pencapaian atau hasil belajar siswa. Hasil belajar tersebut seharusnya betul-betul menggambarkan kemampuan siswa yang semestinya. Dengan 
demikian hasil tersebut dapat membedakan siswa yang sudah memenuhi dan yang belum memenuhi standar yang sudah ditentukan pada standar kompetensi lulusan.

Namun pada kenyataannya informasi yang diperoleh melalui tes belum tentu bisa menjangkau sampai dimensi atau besaran yang hendak diukur oleh tes itu sendiri. Dapat terjadi bahwa hasil tes terkontaminasi dengan besaran selain yang diukur oleh tes bersangkutan. Skor yang diperoleh dari pengujian demikian merupakan skor tidak benar atau timpang. Jika sumber dari ketimpangan skor adalah siswa maka disebut ketidakwajaran skor. Menurut Naga (2001: 43) hal tersebut dapat terjadi jika siswa yang berkemampuan tinggi salah dalam menjawab soal mudah dan siswa yang berkemampuan rendah benar dalam menjawab soal yang sulit, siswa tidak banyak menjawab soal yang mudah, atau seorang siswa menjawab secara acak keseluruhan tes. Hal senada juga diungkap oleh Hulin, Drasgow, and Parsons (1983: 110).

Menurut Nitko (1996: 91 - 94) ketidakwajaran skor dapat juga berasal dari kondisi penilaian. keadaan psikologis siswa, misalnya cemas, khawatir, takut gagal, tidak dapat menulis dengan baik, dapat menyebabkan siswa tidak berhasil menyelesaikan soal secara benar butir-butir tes. Sebagai akibatnya menurut Wiersma \& Jurs (1990: 340) siswa semacam ini akan mendapatkan skor yang tidak tepat, yakni tidak sesuai dengan kemampuan mereka semestinya.

Apabila terjadi ketidakwajaran skor dan hal tersebut sulit dihindari, maka perlu dideteksi ketidakwajaran skor tersebut baik secara individu maupun kelompok. Hasil deteksi dapat digunakan untuk mengambil keputusan yang seuai tentang apa yang harus dilakukan penyelenggara tes terhadap hasil pengukuran tersebut. Ada hal lain yang dapat mempengaruhi dalam perolehan skor, yaitu model penskoran.

Menurut Crocker \& Algina (1986: 399 401) ada tiga model penskoran yang dikenal pada tes pilihan ganda yaitu: 1) penskoran dengan menghitung jumlah jawaban yang benar saja (correct score) sering juga disebut number right score atau conventional scoring, 2) penskoran dengan memberi sanksi pada jawaban yang salah (punishment score) atau rights minus wrong correction, dan 3) penskoran dengan memberi hadiah pada butir yang tidak dijawab (reward score) atau correcting row score, kedua model terakhir ini sering juga disebut sebagai formula scoring. Dalam penelitian ini yang digunakan hanya correct sore (CS) dan punishment score (PS). Penerapan model penskoran yang berbedabeda dapat berdampak pada skor yang diperoleh masing-masing peserta karena peserta akan mempertimbangkan kemungkinan untuk menjawab dengan cara menebak atau tidak menjawab butir soal yang sedang dikerjakan dan pada gilirannya dapat menyebabkan terjadinya ketidakwajaran skor.

Untuk mengetahui atau pendekteksian terhadap ketidakwajaran skor dapat digunakan teori klasik atau dengan teori respon butir. Menurut Naga (2013: 391 - 397) bahwa indeks ketidakwajaran dapat dideteksi melalui pendekatan teori tes, yaitu teori tes klasik (classsical test theory) atau dapat juga diditeksi menggunakan teori test modern (Item Response Theory). Teori tes klasik meliputi indeks Ghiselli, 
Jacob, Donlon dan Fisher, dan metode SHL. Sedangkan pendeteksian dengan teori tes modern meliputi indeks Gauss, residu bakuan kuadrat dan model logaritmik. Dalam penelitian ini yang digunakan adalah Teori tes modern.

Masalah dalam penelitian ini adalah untuk siswa berkemampuan tinggi, apakah yang dikoreksi dengan model penskoran PS memiliki skor wajar lebih tinggi dibandingkan dengan yang dikoreksi dengan model CS?

Menurut Hulin (1983: 112) ketidakwajaran skor secara individu disebut dengan inappropriatennes. Pendeteksian ketidakwajaran skor dapat dicari melalui indeks yang dikenal sebagai indeks kewajaran. Indeks kewajaran diestimasi dengan fungsi kebolehjadian maksimum. Ditambahkan oleh Hulin (1983: 112) bahwa Fungsi kebolehjadian maksimum merupakan perkalian probabilitas keberhasilan dan kegagalan atau perkalian probabilitas jawaban benar dan jawaban salah di dalam menjawab butir tes bersangkutan. Probabilitas tersebut memiliki rentang skor antara 0 sampai dengan 1 , sehingga perkaliannya atau fungsi kebolehjadian akan mencapai nilai maksimum juga terletak diantara 0 dan 1. Namun jika diberikan logaritma kepada fungsi kebolehjadian yang terletak diantara 0 dan 1 tersebut maka nilai logaritma ini akan menjadi negatif. Kebolehjadian maksimum akan menghasilkan nilai logaritma yang paling tinggi atau mendekati 1 , demikian sebaliknya. Dengan demikian, semakin negatif nilai logaritma dari fungsi kebolehjadian, maka makin tidak wajar skor peserta yang bersangutan.

Indeks kesukaran butir dan daya beda butir dalam teori respon butir dikenal sebagai parameter butir. Indeks kesukaran butir dinotasikan sebagai "b" dan indeks daya beda butir dinotasikan sebagai "a". Selain kedua parameter terdapat parameter "c" yang disebut sebagai parameter probabilitas menjawab betul dengan cara menebak jawaban suatu butir. Ketiga parameter tersebut berpengaruh terhadap probabilitas menjawab betul seorang peserta tes pada butir tertentu.

Pada model logistik, ada tiga model yang dikenal yaitu model logistik satu parameter, model logistik dua parameter, dan model logistik tiga parameter. Pada penelitian ini pada awalnya direncanakan menggunakan model logistik tiga parameter, karena jika hanya dua parameter maka hanya melibatkan parameter indeks kesukaran butir dan daya beda butir. Sedangkan kalau tiga parameter di samping indeks kesukaran dan daya beda butir, maka juga melibatkan parameter tebakan. Namun karena keterbatasan peneliti dalam hal pengumpulan data, maka digunakan model logistik satu parameter, yang hanya melibatkan satu parameter yaitu taraf sukar butir.

Model logistik satu parameter (L1P) melibatkan satu parameter, bentuk karakteristik butir L1P (Hambleton, Swaminathan, dan Rogers, 1991: 12) adalah:

$$
\mathrm{P}_{\mathrm{i}}(\theta)=\frac{e^{\left(\theta-b_{i}\right)}}{1+e^{\left(\theta-b_{i}\right)}} \quad \mathrm{i}=1,2,3, \ldots \ldots . ., \mathrm{n}
$$

Dalam mana:
$P_{\mathrm{i}}(\theta)=$ Probabilitas peserta tes dengan kemampuan $\theta$ menjawab butir ke-i dengan benar.
e = Bilangan eksponen yang nilainya mendekati 2,718
$\theta \quad=$ Tingkat kemampuan subjek
$\mathrm{b}_{\mathrm{i}} \quad=$ Parameter indeks kesukaran butir ke-i
$\mathrm{n}=$ Banyaknya butir dalam tes 
Bagi siswa berkemampuan tinggi tidak ada masalah dengan cara penskoran. Dikoreksi dengan model penskoran apapun, mereka tetap akan memilih jawaban yang dianggap betul dulu. Jika ada soal yang dianggap sulit, siswa tersebut tidak akan menjawabnya sampai benar-benar menemukan jawaban yang dianggap paling betul. Berkaitan dengan banyaknya pilihan jawaban, semakin sedikit pilihan jawaban, maka siswa berkemampuan tinggi akan semakin besar peluang menjawab soal dengan betul. Tidak berbeda dengan kelompok siswa berkemampuan tinggi yang dihadapkan pada soal dengan empat pilihan. Siswa dengan kemampuan tinggi akan berpikir beberapa kali dan berhati-hati untuk menebak jawaban jika ragu-ragu terhadap jawaban suatu butir. Dengan demikian dapat diduga bahwa untuk siswa berkemampuan tinggi yang dikoreksi dengan model penskoran PS menghasilkan skor yang lebih wajar dibandingkan penerapan model penskoran CS atau proporsi skor yang dikoreksi dengan model penskoran PS lebih tinggi jika dibandingkan dengan model penskoran CS.

\section{METODOLOGI}

Penelitian ini dilaksanakan pada 4 SMP negeri maupun swasta di kota Palangka Raya. sampel diambil secara acak diperoleh 250 siswa. Pengumpulan data dilaksanakan pada akhir semester genap tahun pelajaran 2015/2016. Adapun tahapannya sebagai berikut: 1) kajian teori, 2) pembuatan instrumen, 3) panel instrumen, 4) ujicoba instrumen, 5) analisis hasil ujicoba, 6) pengambilan data, 7) analisis data, dan 8) penulisan laporan penelitian hasil penelitian, dan 9) penyusunan disertasi.
Penelitian ini merupakan quasi eksperimen dengan menggunakan model perbandingan proporsi. Variabel dalam penelitian ini ada dua yaitu variabel bebas dan variabel terikat. Variabel bebas dalam penelitian ini adalah model penskoran. Model penskoran yang digunakan terdiri atas dua model yakni model penskoran Correct Score (CS) dan Punishment Score (PS). Variabel terikatnya adalah proporsi skor wajar berdasarkan indeks kewajaran skor yang dihitung berdasarkan teori respon butir dengan menggunakan logistik satu parameter. Rancangan penelitian yang digunakan adalah penelitian komparatif, yaitu membandingkan proporsi berdasarkan indeks kewajaran yang diperoleh. Dalam melakukan perbandingan dianalisis secara terpisah terhadap dua kelompok, yaitu siswa dengan pengoreksian model correct score dan punishment score.

Analisis yang dilakukan adalah dengan melihat perbandingan proporsi skor wajar yang diperoleh berdasarkan indeks kewajaran $l_{g z}$ yang diperoleh antara siswa yang dikoreksi dengan model penskoran correct score dan punishment score. Analisis dilakukan terhadap kelompok siswa berkemampuan tinggi setelah siswa diurutkan berdasarkan estimasi kemampuan siswa yang diperoleh. Kemudian dilihat perbandingan proporsinya dengan batas indeks kewajaran $I_{g z}=0$.

Model penskoran Correct Score (CS), hasil jawaban peserta dikoreksi jika benar diberi skor satu dan jika salah atau tidak dijawab diberi skor nol, selanjutnya menjumlahkan jawaban benar pada setiap butir. Model penskoran dengan hukuman atau Punishment Score (PS) yaitu menjumlahkan jawaban benar dan 
menguranginya dengan hasil bagi banyak butir yang dijawab salah dengan banyak pilihan di kurangi satu.

Data penelitian mengenai nilai indeks kewajaran $\left(I_{g z}\right)$ dihitung berdasarkan rumus indeks kewajaran skor setelah parameter butir dan kemampuan responden diestimasi. Sedangkan tingkat kemampuan $(\theta)$ diperoleh setelah estimasi kemampuan dan parameter butir didapat melalui perhitungan dengan program Bilog.

Sebelum dilakukan analisis data, terlebih dahulu dilakukan uji kecocokan model yaitu menguji apakah model logistik satu parameter cocok digunakan untuk data yang diperoleh dari lapangan. Caranya dengan melihat pemenuhan syarat model. Persyaratan model dilihat dari hasil program Bilog pada saat melakukan estimasi parameter butir dan kemampuan. Persyaratan yang diuji antara lain persyaratan unidimensi dan invariansi baik invariansi parameter butir maupun invariansi parameter peserta. Syarat unidimensi dilakukan dengan analsiis faktor (program SPSS) dan invariansi dilakukan menggunakan korelasi Product Moment (Ecxel). Setelah persyaratan model dan persyaratan analisis dipenuhi, maka dilakukan pengujian hipotesis penelitian melalui pengujian hipotesis statistik yang dirumuskan. Analisis data dilakukan dengan analisis perbedaan proporsi dengan statistik $Z$ berikut: (Walpole, 1992: 321)

$$
z=\frac{p_{1}-p_{2}}{\sqrt{p q\left[\left(\frac{1}{n_{1}}\right)+\left(\frac{1}{n_{2}}\right)\right]}}
$$

Hipotesis yang diuji sebagai berikut:

Ho: $\pi_{\mathrm{PS}} \leq \pi_{\mathrm{CS}}$

Ha: $\pi_{\mathrm{PS}}>\pi_{\mathrm{CS}}$
$\pi_{\mathrm{PS}}=$ indeks skor wajar siswa yang dikoreksi dengan model penskoran Punishment Score.

$\pi_{\mathrm{CS}}=$ indeks skor wajar siswa yang dikoreksi dengan model penskoran Correct Score

\section{HASIL DAN PEMBAHASAN}

Kelompok skor yang diperoleh dari model pensekoran Correct Score (CS), yaitu cara pensekoran dengan menjumlahkan seluruh jawaban siswa yang betul. Terdapat 250 lembar jawaban yang masing-masing terdiri dari 30 butir soal. Butir soal yang dijawab betul diberi skor 1 sedangkan yang salah 0 , dan yang tidak dijawab juga diberi skor 0 . Jadi dengan cara penskoran seperti ini skor maksimal yang diperoleh siswa yaitu 30 dan yang terendah adalah 0 . Skor tertinggi adalah 21 dan terendah adalah 3 dengan rentang sebesar 18 . Diperoleh juga rata-rata sebesar 11,448 simpangan baku 3,318. Distribusi frekuensi dan histogram skor model penskoran correct score disajikan dalam tabel 1 dan gambar 1.

Penskoran dengan model Punishment Score (PS) atau penskoran dengan hukuman adalah penskoran dengan cara menjumlahkan skor jawaban betul dan menguranginya dengan skor jawaban yang salah dibagi banyaknya pilihan dikurangi satu dari setiap lembar jawaban siswa. Diperoleh data skor tertinggi adalah 27 dan terendah adalah -9 dengan rentang sebesar 36 . Diperoleh juga rata-rata sebesar 4,62 simpangan baku 6,53. Distribusi frekuensi dan histogram skor model penskoran punishment score untuk soal dengan tiga pilihan disajikan dalam tabel 2 dan gambar 2. 
Sugiharto, Perbedaan Ketidakwajaran Skor Berdasarkan Teori Respon Butir Ditinjau dari Model...

Tabel 1. Distribusi frekuensi skor dengan model penskoran correct score

\begin{tabular}{cccccc}
\hline No & Interval & Nilai tengah & Frekuensi & Frek. relatif & Frek. rel kum \\
\hline 1. & $3-5$ & 4 & 5 & 2 & 2 \\
2. & $6-8$ & 7 & 38 & 15,2 & 17,2 \\
3. & $9-11$ & 10 & 97 & 38,8 & 56 \\
4. & $12-14$ & 13 & 63 & 25,2 & 81,2 \\
5. & $15-17$ & 16 & 38 & 15,2 & 96,4 \\
6. & $18-20$ & 17 & 8 & 3,2 & 99,6 \\
7. & $21-23$ & 22 & 1 & 0,4 & 100 \\
8. & $24-26$ & 25 & 0 & 0 & \\
\hline
\end{tabular}

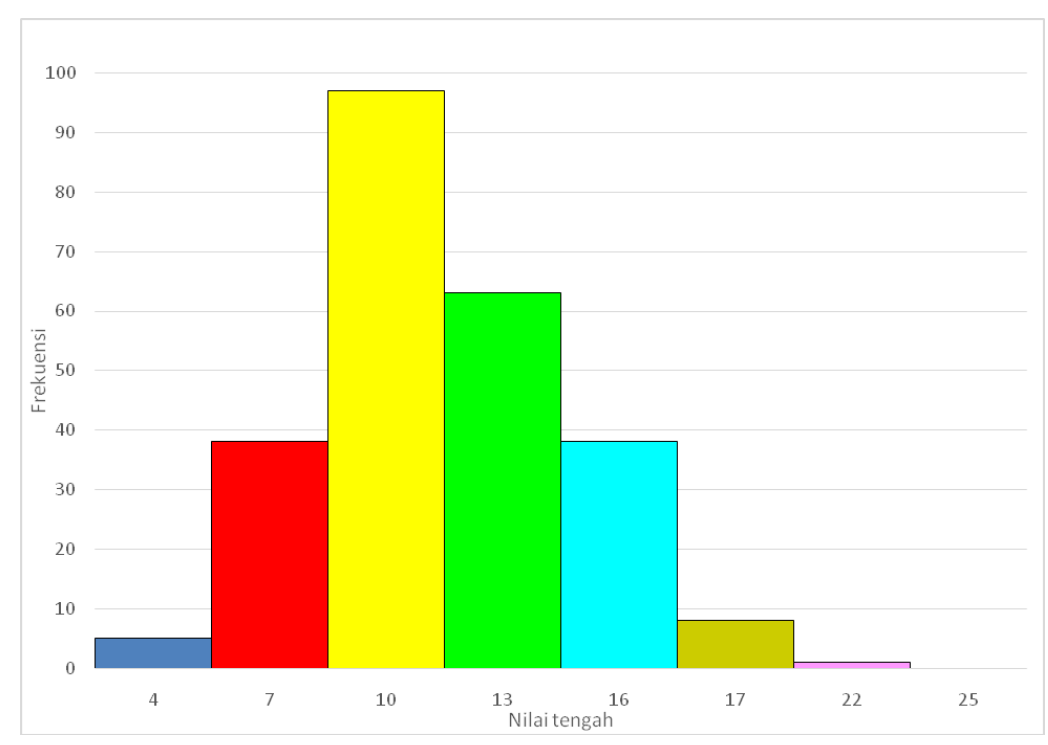

Gambar 1. Histogram skor dengan model penskoran correct score

Tabel 2. Distribusi frekuensi skor dengan model penskoran punishment score

\begin{tabular}{|c|c|c|c|c|c|}
\hline No. & Interval & Nilai tengah & Frekuensi & Frek. relatif & Frek. rel kum \\
\hline 1. & $-9,00-(-4,41)$ & $-6,705$ & 16 & 6,4 & 6,4 \\
\hline 2. & $-4,40-0,19)$ & $-2,295$ & 54 & 21,6 & 28 \\
\hline 3. & $0,20-4,79$ & 2,495 & 77 & 30,8 & 58,8 \\
\hline 4. & $4,80-9,39$ & 7,095 & 50 & 20 & 78,8 \\
\hline 5. & $9,40-13,99$ & 11,695 & 24 & 9,6 & 88,4 \\
\hline 6. & $14,00-18,59$ & 16,295 & 24 & 9,6 & 98 \\
\hline 7. & $18,60-23,19$ & 20,895 & 2 & 0,8 & 98,8 \\
\hline 8. & $23,20-27,79$ & 25,495 & 3 & 1,2 & 100 \\
\hline & & & 250 & 100 & \\
\hline
\end{tabular}




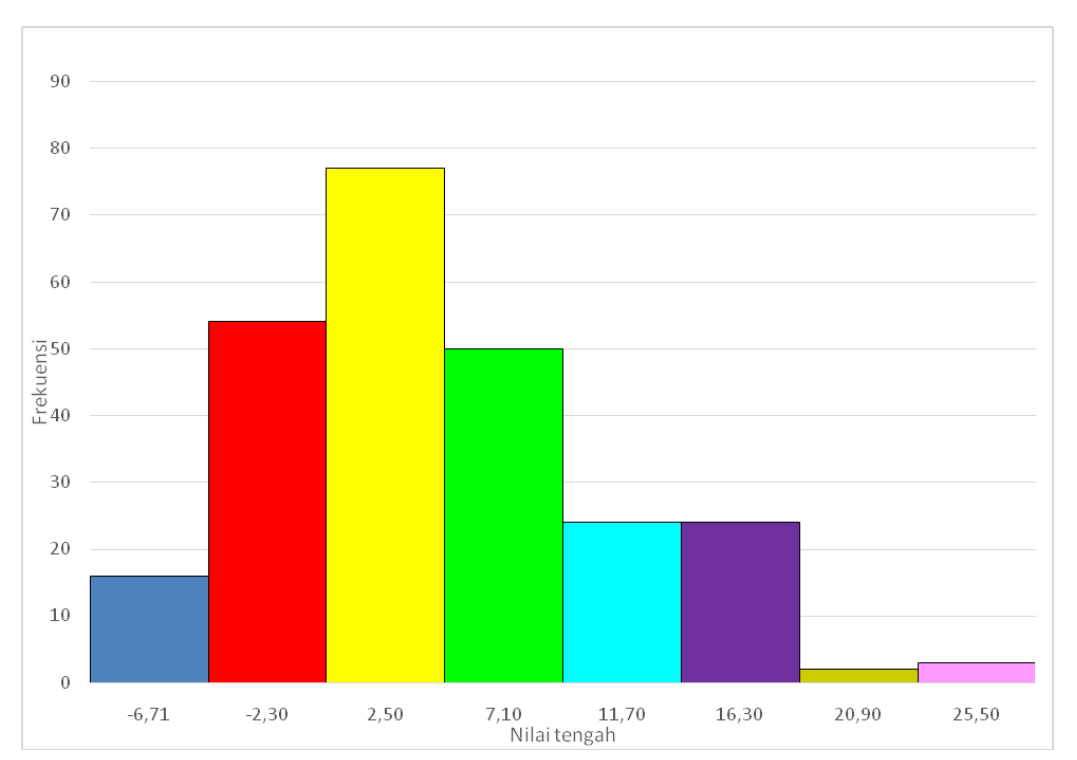

Gambar 2. Histogram skor dengan model penskoran punishment score

Tabel 3. Hasil estimasi parameter butir

\begin{tabular}{cccc}
\hline No. Butir & CS3 & No. Butir & CS3 \\
\hline 1 & 0.532 & 16 & 0.406 \\
2 & -0.057 & 17 & 0.232 \\
3 & 0.244 & 18 & 0.066 \\
4 & -0.136 & 19 & -0.006 \\
5 & -0.077 & 20 & 0.077 \\
6 & 0.153 & 21 & 0.220 \\
7 & 0.131 & 22 & -0.292 \\
8 & 0.077 & 23 & 0.131 \\
9 & -0.486 & 24 & -0.546 \\
10 & -0.379 & 25 & -0.516 \\
11 & 0.232 & 26 & 0.175 \\
12 & 0.291 & 27 & 0.120 \\
13 & 0.088 & 28 & -0.097 \\
14 & -0.087 & 29 & -0.117 \\
15 & 0.066 & 30 & -0.447 \\
\hline & & Min & $-0,546$ \\
\hline & & Maks & 0,532 \\
\hline
\end{tabular}

\begin{tabular}{cccc}
\hline No. Butir & PS3 & No. Butir & PS3 \\
\hline 1 & 0.376 & 16 & 0.278 \\
2 & -0.121 & 17 & 0.329 \\
3 & 0.087 & 18 & -0.054 \\
4 & -0.077 & 19 & 0.118 \\
5 & -0.183 & 20 & 0.385 \\
6 & 0.542 & 21 & 0.183 \\
7 & -0.032 & 22 & -0.273 \\
8 & -0.099 & 23 & 0.260 \\
9 & -0.543 & 24 & -0.397 \\
10 & -0.318 & 25 & -0.526 \\
11 & 0.172 & 26 & 0.066 \\
12 & 0.260 & 27 & -0.073 \\
13 & 0.558 & 28 & -0.207 \\
14 & -0.328 & 29 & 0.126 \\
15 & 0.025 & 30 & -0.532 \\
\hline & & Min & -0.543 \\
\hline & & Maks & 0.558 \\
\hline
\end{tabular}


Sugiharto, Perbedaan Ketidakwajaran Skor Berdasarkan Teori Respon Butir Ditinjau dari Model...

Estimasi parameter dilakuan dengan menggunakan program Bilog, yakni perangkat lunak untuk mengestimasi parameter butir dan kemampuan siswa berdasarkan fungsi karakteristik butir logistik satu parameter. Dari proses estimasi tersebut diperoleh estimasi parameter butir berupa taraf sukar butir dan kemampuan siswa $(\theta)$. Hasil estimasi parameter butir (Indeks Kesukaran) disajikan dalam tabel 3.

Berdasarkan hasil estimasi parameter taraf kesukaran butir (b) diperoleh harga-harga parameter mulai dari $-1,475$ sampai 1,253 , berarti distribusi soal mulai dari sangat mudah sampai dengan sangat sukar. Rangkuman indeks taraf sukar berdasarkan Tabel 4 dikelompokkan ke dalam lima kelompok dapat dilihat pada tabel 4 .

Tabel 4. Rangkuman indeks taraf sukar

\begin{tabular}{cccl}
\hline Taraf Sukar & CS3 & PS3 & \multicolumn{1}{c}{ Kategori } \\
\hline$(-2,00)-(-1,30)$ & 0 & 0 & Sangat Mudah \\
$(-1,20)-(-0,41)$ & 4 & 3 & Mudah \\
$(-0,40)-(0,39)$ & 24 & 25 & Sedang \\
$0,40-1,20$ & 2 & 2 & Sukar \\
$1,19-2,00$ & 0 & 0 & Sangat Sukar \\
\hline Jumlah & 30 & 30 & \\
\hline
\end{tabular}

Untuk butir kategori sedang $(-0,40-(0,39))$ cukup banyak pada kelompok PS3 sebanyak 25 butir atau sekitar $83,33 \%$ dan pada kelompok CS3 sebanyak 24 butir atau sekitar $80 \%$. Untuk kategori butir sukar sebanyak dua butir atau sekitar 6,67\% terdapat pada kelompok CS3 dan PS3. Tabel 5 disajikan sebaran butir-butir dilihat dari taraf sukar. Sedangkan hasil estimasi parameter kemampuan $(\theta)$ menggunakan program Bilog disajikan pada tabel 6 .
Tabel 5. Sebaran butir berdasarkan taraf sukar

\begin{tabular}{lcc}
\hline Kategori Soal & CS3 & PS3 \\
\hline sangat mudah & - & - \\
\hline mudah & $9,24,30,25$ & $9,25,30$ \\
\hline & $2,3,4,5,6,7,8$, & $1,2,3,4,5,7,8$, \\
& $10,11,12,13$, & $10,11,12,14$, \\
sedang & $14,15,17,18$, & $15,16,17,18,1$ \\
& $19,20,21,22$, & $920,21,22,23$, \\
& $23,26,27,28$, & $24,26,27$, \\
& 29 & 28,29 \\
\hline sukar & 1,16 & 6,3 \\
\hline sangat sukar & - & - \\
\hline jumlah & 30 & 30 \\
\hline
\end{tabular}

Hasil estimasi parameter kemampuan $(\theta)$ menggunakan program Bilog disajikan pada tabel 6.

Tabel 6. Sebaran estimasi kemampuan siswa

\begin{tabular}{lcc}
\hline Kemampuan & CS3 & PS3 \\
\hline$(-2,4)-(-1,6)$ & & \\
$(-1,5)-(-0,0)$ & 16 & 8 \\
$(-0,6)-(-0,2)$ & 202 & 185 \\
$0,3-1,1$ & 32 & 54 \\
$1,2-2,0$ & & 3 \\
\hline jumlah & 250 & 250 \\
\hline minimum & $-1,335$ & $-1,255$ \\
\hline maksimum & 0,448 & 1,430 \\
\hline rerata & $-0,324$ & $-0,195$ \\
\hline
\end{tabular}

Berdasarkan tabel di atas bahwa kemampuan siswa dimulai dari kemampuan paling rendah $-2,312$ sampai kemampuan yang paling tinggi 2,062.

Tabel 7. Sebaran tingkat kemampuan berdasarkan kelompok kemampuan

\begin{tabular}{lcc}
\hline Kemampuan & CS3 & PS3 \\
\hline Rendah & $16(6,4 \%)$ & $8(3,2 \%)$ \\
Sedang & $202(80,8 \%)$ & $185(74 \%)$ \\
Tinggi & $32(12,8 \%)$ & $57(22,8 \%)$ \\
\hline
\end{tabular}


Tabel 8. Sebaran indeks kewajaran skor kelompok CS

\begin{tabular}{cccc}
\hline \multirow{2}{*}{ Skor } & Indeks Kewajaran & Frekuensi & Jumlah/Proporsi \\
\cline { 3 - 4 } Tak wajar & $<(-2,000)$ & $\theta$ tinggi & $\theta$ tinggi \\
& $(-2,000)-(-1,001)$ & 1 & \\
& $(-1,000)-0,000$ & 2 & 0,438 \\
Jumlah & 11 & \\
\hline \multirow{3}{*}{ Wajar } & $0,001-1,000$ & $\mathbf{1 4}$ & \\
& $1,001-2,000$ & 14 & 0,562 \\
& $>2,000$ & 3 & \\
\hline \multirow{4}{*}{ Jumlah } & 1 & 1,000 \\
\hline & Total & $\mathbf{1 8}$ & \\
\hline & Minimum & $-2,775$ & \\
\hline
\end{tabular}

Tabel 9. Sebaran indeks kewajaran skor kelompok PS

\begin{tabular}{|c|c|c|c|}
\hline \multirow{2}{*}{ Skor } & \multirow{2}{*}{ Indeks Kewajaran } & Frekuensi & Jumlah/Proporsi \\
\hline & & $\theta$ tinggi & $\theta$ tinggi \\
\hline \multirow{4}{*}{ Tak wajar } & $<(-2,000)$ & 1 & \multirow{4}{*}{0,737} \\
\hline & $(-2,000)-(-1,001)$ & - & \\
\hline & $(-1,000)-0,000$ & 42 & \\
\hline & Jumlah & 42 & \\
\hline \multirow{4}{*}{ Wajar } & $0,001-1,000$ & 12 & \multirow{4}{*}{0,263} \\
\hline & $1,001-2,000$ & - & \\
\hline & $>2,000$ & 3 & \\
\hline & Jumlah & 15 & \\
\hline & Total & 57 & 1,000 \\
\hline & Minimum & $-0,996$ & \\
\hline & Maksimum & 4,393 & \\
\hline & Rerata & $-1,714 \times 10^{-15}$ & \\
\hline
\end{tabular}

Perhitungan indeks kewajaran $\ell_{g z}$ diperoleh 18 siswa mempunyai skor wajar dan 14 siswa mempunyai skor tidak wajar dari 32 siswa dengan kemampuan tinggi. Sebaran indeks kewajaran $\ell_{g z}$ untuk kelompok CS dapat diikuti pada tabel 8. Sedangkan indeks kewajaran skor siswa yang mengerjakan soal empat pilihan dengan model punishment score terlihat pada tabel 9.

Uji persyaratan analisis unidimensi dimaksudkan untuk mengetahui apakah setiap butir mengukur satu macam ciri dari seluruh peserta tes. Pemeriksaan persyaratan unidimensi 
dilakukan dengan menggunakan analisis faktor dengan melihat salah satu faktor analisis yaitu nilai eigen. Apabila nilai eigen faktor pertama mempunyai nilai yang dominan dibandingkan dengan nilai eigen faktor kedua dan seterusnya mempunyai nilai eigen hampir sama, maka dapat dikatakan bahwa syarat unidimensi terpenuhi.

Pengujian invariansi parameter butir adalah: 1) mengurutkan kemampuan peserta dari yang terendah sampai tertinggi atau sebaliknya, 2) mengambil $27 \%$ jawaban siswa baik kelompok bawah maupun kelompok atas, 3) mengestimasi parameter butir kedua kelompok tersebut, dan 4) mengkorelasikan parameter kelompok atas dengan parameter kelompok bawah. Jika hasil $r_{\text {hitung }}$ lebih besar atau sama dengan $r_{\text {tabel, }}$ maka terdapat invariansi butir.

Uji persyaratan analisis unidimensi dimaksudkan untuk mengetahui apakah setiap butir mengukur satu macam ciri dari seluruh peserta tes. Pemeriksaan persyaratan unidimensi dilakukan dengan menggunakan analisis faktor dengan melihat salah satu faktor analisis yaitu nilai eigen. Apabila nilai eigen faktor pertama mempunyai nilai yang dominan dibandingkan dengan nilai eigen faktor kedua dan seterusnya mempunyai nilai eigen hampir sama, maka dapat dikatakan bahwa syarat unidimensi terpenuhi.

Pengujian invariansi parameter butir adalah: 1) mengurutkan kemampuan peserta dari yang terendah sampai tertinggi atau sebaliknya, 2) mengambil $27 \%$ jawaban siswa baik kelompok bawah maupun kelompok atas, 3) mengestimasi parameter butir kedua kelompok tersebut, dan 4) mengkorelasikan parameter kelompok atas dengan parameter kelompok bawah. Jika hasil $r_{\text {hitung }}$ lebih besar atau sama dengan $r_{\text {tabel }}$, maka terdapat invariansi butir. Nilai korelasi parameter butir disajikan pada tabel 10 .

Tabel 10. Nilai korelasi parameter butir

\begin{tabular}{cccc}
\hline Parameter & CS3 & PS3 & $\mathbf{r}_{\text {tabel }}$ \\
\hline Taraf Sukar & 0,416 & 0,487 & 0,361 \\
\hline
\end{tabular}

Dari tabel di atas terlihat bahwa seluruh nilai korelasi atau $r_{\text {hitung }}$ lebih besar dari $r_{\text {tabel }}$, sehingga dapat disimpulkan bahwa terdapat invariansi parameter butir untuk semua kelompok.

Pengujian invariansi parameter kemampuan siswa adalah: 1) membagi dua butir tes menjadi dua bagian berdasarkan butir ganjil dan genap. Sehingga masing-masing terdiri atas 15 butir ganjil dan 15 butir genap, 2) mengestimasi parameter kemampuan pada kedua kelompok tersebut, 3) mengkorelasikan kemampuan hasil estimasi untuk kedua

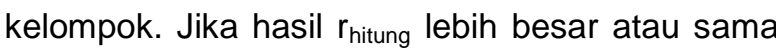
dengan $r_{\text {tabel}}$, maka terdapat invariansi kemampuan siswa. Nilai korelasi parameter kemampuan siswa disajikan pada tabel 11.

Tabel 11. Nilai korelasi parameter kemampuan siswa

\begin{tabular}{cccc}
\hline Parameter & CS3 & PS3 & $\mathbf{r}_{\text {tabel }}$ \\
\hline Taraf Sukar & 0,297 & 0,522 & 0,123 \\
\hline
\end{tabular}

Dari tabel di atas terlihat bahwa seluruh nilai korelasi atau $r_{\text {hitung }}$ lebih besar dari $r_{\text {tabel }}$, sehingga dapat disimpulkan bahwa terdapat invariansi parameter kemampuan siswa untuk semua kelompok.

Uji Hipotesis untuk kelompok siswa yang dikoreksi dengan model PS dan CS, pada siswa dengan $\theta$ tinggi. 
Ho: $\pi_{\mathrm{PS}} \leq \pi_{\mathrm{CS}}$

$\mathrm{Ha}: \pi_{\mathrm{PS}}>\pi_{\mathrm{CS}}$

Berdasarkan hasil perhitungan diperoleh harga-harga sebagai berikut:

$x_{1}=15 \quad x_{2}=18$

$n_{1}=57 n_{2}=32$

$\mathrm{p}_{1}=\frac{x_{1}}{n_{1}},=\frac{15}{57}=0,263 \quad \mathrm{p}_{2}=\frac{x_{2}}{n_{2}}=\frac{18}{32}=$

0,563

$\mathrm{p}=\frac{x_{1}+x_{2}}{n_{1}+n_{2}}=\frac{15+18}{57+32}=\frac{33}{89}=0,371$

$q=1-0,371=0,629$

$z=\frac{p_{1}-p_{2}}{\sqrt{p q\left[\left(\frac{1}{n_{1}}\right)+\left(\frac{1}{n_{2}}\right)\right]}}$

$z=\frac{0,263-0,563}{\sqrt{0,3719,629] 0,018+0,031}}=-2,806$

Ternyata $Z_{\text {hitung }}$ sebesar $-2,806$, sedangkan $Z_{\text {tabel }}$ adalah $-1,65$ sehingga $Z_{\text {hitung }}$ berada dalam daerah penolakan $\mathrm{H}_{0}$. Hal ini menunjukkan bahwa pada siswa berkemampuan tinggi untuk model penskoran punishment score menjaring skor lebih banyak dibandingkan dengan model penskoran correct score dengan perbedaan proporsi yang signifikan. Dapat dikatakan bahwa siswa yang dikoreksi dengan model penskoran punishment score mempunyai indeks kewajaran yang lebih baik dibandingkan dengan indeks kewajaran siswa yang dikoreksi dengan model penskoran correct score.

Hasil pengujian siswa yang berkemampuan tinggi menunjukkan bahwa model penskoran menghasilkan proporsi skor wajar berbeda. Dilihat dari proporsi untuk siswa berkemampuan rendah pada model correct score sebesar $43,8 \%$ dan pada model punishment score sebesar $62,5 \%$. Sedangkan proporsi untuk siswa berkemampuan tinggi pada model correct score sebesar 56,3\% dan pada model punishment score sebesar 26,3\%. Hal ini menunjukkan bahwa model penskoran memang berpengaruh terhadap banyak pilihan jawaban.

\section{KESIMPULAN}

Siswa berkemampuan tinggi untuk model penskoran punishment score menjaring skor lebih banyak dibandingkan dengan model penskoran correct score dengan perbedaan proporsi yang signifikan. Dapat dikatakan bahwa siswa yang dikoreksi dengan model penskoran PS memiliki skor wajar lebih tinggi dibandingkan dengan yang dikoreksi dengan model CS.

\section{DAFTAR PUSTAKA}

Hambleton, R.K., Swaminathan, H. and Rogers, H.J. Fundamental of Item Response Theory. (London: Sage Publication, In. 1991). h. 12.

Hulin, C. I., Drasgow, P. and Parsons, C.K. Item Response Theory Application to Psychological Measurement. (USA: Dow Jones-Irwin. 1983). h. 110.

Nitko, A. J. Educational Assessment of Students. $\left(2^{\text {nd }}\right.$ ed). (Columbus Ohio: Prentice Hall. 1996). hh. 91-94.

Naga, D. S. Indeks Kehati-hatian Sekor Responden pada Model SHL: Suatu Bentuk Indeks Ketidakwajaran pada Sekor Ujian. (Jurnal IImiah Psikologi "Arkhe". Tahun 6, Nomor 1. 2001). h. 43.

Teori Sekor pada Pengukuran Mental. (Jakarta: PT. Nagarani Citrayasa. 2013). hh. 391 - 397 
Walpole, R. E. Pengantar Statistik. (Jakarta: PT Gramedia Pustaka Utama. 1992). h. 321

Wiersma, W. \& Jurs, S.G.. Educational Measurement and Testing. (2 ${ }^{\text {nd }}$ ed.). (Boston: Allyn and Bacon. 1990). h. 340 